CASSOWARY 3 (1): 21 - 31

ISSN : 2614-8900

E-ISSN : 2622-6545

CProgram Pascasarjana Universitas Papua, https://pasca.unipa.ac.id/

\title{
Suhu inkubasi, pasir pantai peneluran dan sukses penetasan telur penyu pada sarang semi alami di Pantai Warebar - Yenbekaki Distrik Waigeo Timur, Kabupaten Raja Ampat
}

\begin{abstract}
Incubation temperatures, nesting beach and hatching success of sea turtles in semi-natural nests at Warebar Beach - Yenbekaki, Sub District Waigeo, Raja Ampat
\end{abstract}

Aditya P. Tarigan ${ }^{1}$, Ricardo F. Tapilatu ${ }^{2 *}$, Marthin Matulessy ${ }^{1}$

${ }^{1}$ Jurusan Ilmu Kelautan, Fakultas Perikanan dan Ilmu Kelautan, Universitas Papua

${ }^{2}$ Program Studi S2 Sumberdaya Akuatik (SDA), Program Pascasarjana, Universitas Papua

Jl. Gunung Salju, Amban, Manokwari 98314 Papua Barat, Indonesia

*Email: $\underline{\text { rf.tapilatu@unipa.ac.id }}$

\begin{abstract}
The research took place between May and October 2019, and divided into two stages. The first stage was field research to collect data by identifying turtles, calculating hatching successes, measuring the temperature of the nesting beach and nest temperature of each species of turtle in semi-natural nests at Warebar Beach, Yenbekaki village, East Waigeo Sub District, Raja Ampat. The second stage after the field was conducting an analysis of hatching rate in hatchery, sand temperature and nest temperature for each species of turtle. The species of turtles nesting at Warebar Beach are olive-ridley (Lepidochelys olivacea) and hawksbill (Eretmochelys imbricata) turtles. Based on the measurement results at semi-natural nests, it was obtained that the hatching rate of olive ridley sea turtle was $71.6 \% \pm 28.3(\mathrm{X} \pm \mathrm{SD})$ and hawksbill sea turtle was $59.8 \% \pm 41.3$, the overall mean temperature of nesting beach was $28^{\circ} \mathrm{C}$, the mean incubation temperature for both sea turtle species was $31^{\circ} \mathrm{C}$.
\end{abstract}

Keywords: Semi-natural nest, hatching success, nesting beach temperatures, nest incubation temperatures

ABSTRAK: Penelitian berlangsung dari bulan Mei-Oktober 2019, terbagi dalam dua tahap. Tahap pertama yaitu penelitian lapangan untuk pengambilan data dengan mengidentifikasi penyu, penghitungan sukses penetasan telur, pengukuran suhu pasir pantai peneluran dan suhu sarang tiap jenis penyu pada sarang semi alami di Pantai Warebar Kampung Yenbekaki Distrik Waigeo Timur Kabupaten Raja Ampat. Tahap kedua pasca lapangan yaitu melakukan analisa sukses penetasan, suhu pasir dan suhu sarang tiap jenis penyu. Jenis penyu yang melakukan aktivitas peneluran di Pantai Warebar adalah penyu lekang (Lepidochelys olivacea) dan penyu sisik (Eretmochelys imbricata). Berdasarkan hasil pengukuran di sarang semi alami diperoleh sukses penetasan penyu lekang sebesar $71.6 \% \% \pm 28.3^{\circ} \mathrm{C}(\mathrm{X} \pm \mathrm{SD})$ dan penyu lekang sebesar $59.8 \%$, rata-rata keseluruhan suhu pasir pantai peneluran sebesar $28^{\circ} \mathrm{C}$, rata-rata suhu inkubasi sarang penyu lekang dan sarang penyu sisik sebesar $31^{\circ} \mathrm{C}$. 
Kata kunci: sarang semi alami, sukses penetasan, suhu pasir pantai peneluran, suhu inkubasi sarang

\section{PENDAHULUAN}

Penyu merupakan reptil yang hidup di laut serta mampu bermigrasi dalam jarak jauh. Terdapat 7 jenis penyu yang ada di dunia, 6 diantaranya hidup di perairan Indonesia yaitu penyu belimbing (Dermochelys coriacea), penyu hijau (Chelonia mydas), penyu sisik (Eretmochelys imbricata), penyu lekang (Lepidochelys olivacea), penyu tempayan (Caretta caretta) dan penyu pipih (Natator depressus). Semua jenis penyu dikelompokkan sebagai endangered species dalam IUCN (International Union for the Conservation of Nature and Natural Resources) Red list yakni species yang dalam waktu dekat sangat beresiko mengalami kepunahan. Melihat hal tersebut, maka konservasi penyu merupakan suatu tindakan yang sangat penting dan mendesak untuk dilakukan (IUCN, 2019).

Keberadaan penyu telah lama terancam, baik dari alam maupun aktivi-tas kegiatan manusia yang membahayakan populasinya secara langsung maupun tidak langsung. Aktivitas pengambilan telur penyu untuk tujuan ekonomis dan pemenuhan kebutuhan protein hewani oleh masyarakat juga turut mempercepat laju penurunan populasi satwa laut ini. Penyu telah lama menjadi sasaran perburuan manusia, mulai dari penyu betina dewasa yang merayap menuju pantai, telur-telur yang berada di dalam sarang sampai penyu dewasa yang berada di laut (Dermawan et al, 2009).

Keberadaan populasi dialam dapat dijaga dari ancaman kepunahan dengan melakukan pembinaan populasi di pantai-pantai peneluran melalui penetasan semi alami atau penangkaran. Pantai Yenbekaki yang terletak di Distrik Waigeo Utara, Kabupaten Raja
Ampat merupakan salah satu tempat penangkaran penyu. Wilayah ini diharapkan dapat menjadi tempat penang-karan yang baik. Namun demikian untuk memperoleh hasil yang diharapkan, perlu kiranya dipelajari berbagai aspek biologi dan ekologi dari penyu tersebut yang berperan dan dapat mempengaruhi hasil penetasan.

Salah satu faktor lingkungan yang besar mempengaruhi keberhasilan pene-tasan telur penyu yaitu suhu inkubasi. Suhu sarang selain berpe-ngaruh pada lama waktu pengeraman juga berpengaruh terhadap kehidupan janin yang sedang berkembang. Suhu yang terlalu rendah disamping memperlambat perkembangan juga dapat mengancam kehidupan janin begitu pula bila suhu lingkungan terlalu tinggi, meskipun di sisi lain peningkatan suhu dapat mempercepat waktu penetasan. Tapilatu dan Ballamu, (2015) juga menambahkan bahwa dalam kisaran suhu $24-32^{\circ} \mathrm{C}$, perubahan $1^{\circ} \mathrm{C}$ akan menambah atau mempercepat masa inkubasi selama 5 hari.

Berdasarkan kondisi diatas maka dilakukan penelitian tentang profil suhu inkubasi, suhu pantai peneluran dan sukses penetasan penyu di Pantai Yenbekaki, Distrik Waigeo Timur yang merupakan salah satu kawasan penangkaran penyu di Raja Ampat. yaitu:

Adapun tujuan penelitian ini

1. Mengetahui profil suhu inkubasi sarang semi alami penyu di Pantai Warebar Yenbekaki, Distrik Waigeo Timur.

2. Mengetahui profil suhu pasir di Pantai Warebar

3. Mengetahui sukses penetasan telur penyu pada sarang semi alami di Pantai Warebar. 


\section{MATERI DAN METODE Waktu dan tempat}

Penelitian ini dilaksanakan selama 4 bulan yaitu pada bulan Mei Agustus 2019 di Pantai Warebar Kampung Yenbekaki, Distrik Waigeo Timur, Kabupaten Raja Ampat, Provinsi Papua Barat (Gambar 1).

\section{Variabel pengamatan}

Variabel yang diamati dalam penelitian ini yaitu (1). suhu inkubasi sarang, (2). suhu pasir pantai peneluran dan (3). sukses penetasan telur penyu.

\section{Metode pengambilan data}

Data yang digunakan dalam penelitian ini yaitu data primer dan data sekunder. Data primer yaitu pengukuran atau observasi langsung dilapangan. Sedangkan data sekunder yaitu mengambil sumber-sumber kajian terkait bahan penelitian. Berikut metode pengambilan data langsung dilapangan:

\section{Suhu inkubasi sarang semi alami}

Pengukuran suhu inkubasi sarang relokasi dengan menggunakan logger suhu. Logger suhu ini ditanam di bagian tengah tumpukan telur pada masingmasing sarang relokasi tiap spesies selama 2 bulan hingga telur menetas. Logger suhu tersebut akan mencatat suhu inkubasi sarang setiap satu jam. Kemudian data ini di download menggunakan software Hoboware dan kemudian diekspor ke Microsoft Excel.

\section{Suhu Inkubasi dan Pasir Pantai}

Pengukuran suhu pasir dengan menggunakan logger suhu. Logger suhu ditanam pada kedalaman $80 \mathrm{~cm}$ dengan posisi yang berada di bawah naungan vegetasi. Kedalaman $80 \mathrm{~cm}$ diasumsikan sebagai kedalaman sarang penyu belimbing (DKP, 2009). Penempatan temperature datalogger ini telah dilakukan pada tanggal 13 April 2019 untuk memonitor suhu pasir dengan asumsi penyu belimbing yang akan dominan bertelur seperti pada musim peneluran 2018. Logger suhu ditanam selama kurang lebih 3 bulan. Kemudian data dari logger suhu di download menggunakan software Hoboware dan kemudian diekspor ke Microsoft Excel untuk keperluan analisis.

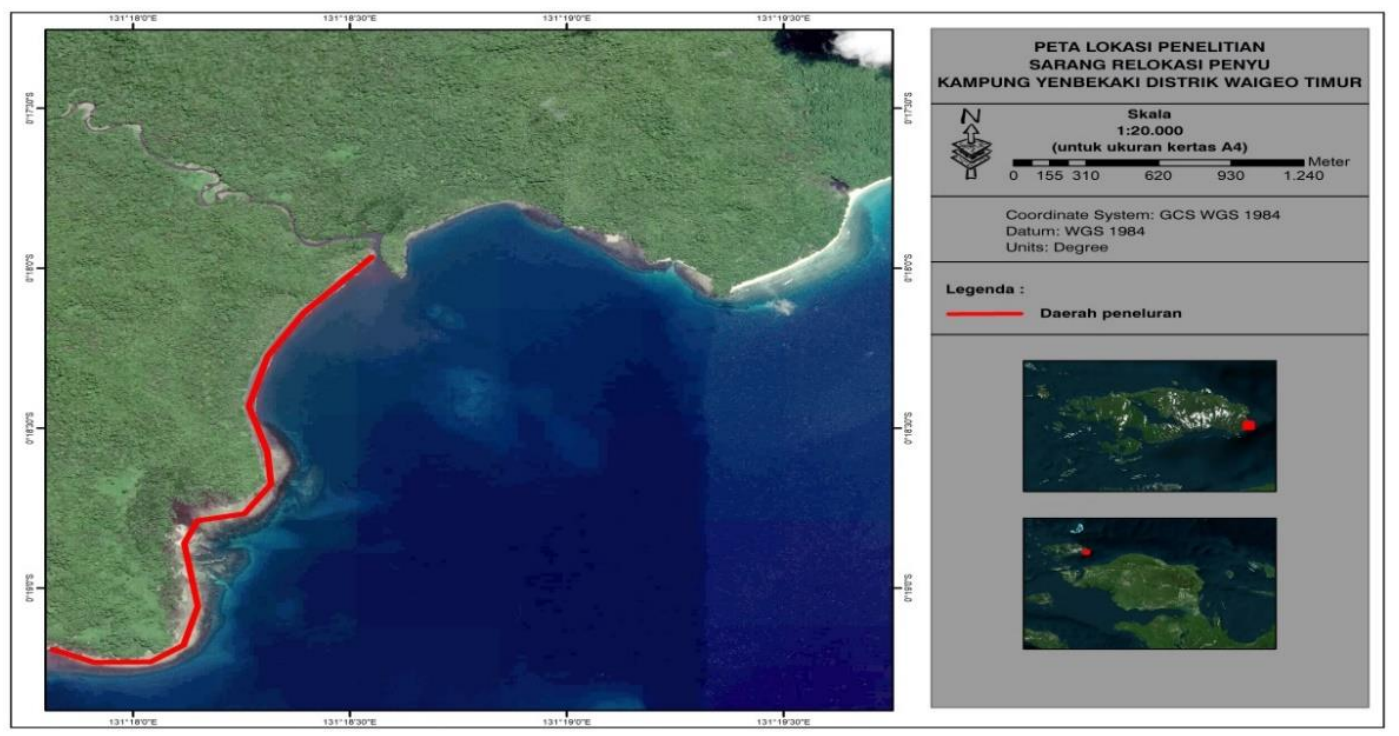

Gambar 1. Peta Lokasi Penelitian Pantai Warebar Yenbekaki 


\section{Sukses penetasan telur penyu di sa- rang semi alami}

Pengamatan terhadap daya tetas telur dilakukan dengan menggali sarang yang sudah menetas. Setelah menggali sarang maka akan diamati jumlah tukik yang muncul ke permukaan pasir (E), jumlah cangkang telur (diberi kode $\mathrm{S}$ ) yang mengindikasikan jumlah tukik yang menetas (Catatan: hanya cangkang yang $>50 \%$ dari total telur yang dihitung. Fragmen kecil tidak perlu dihitung). Kemudian jumlah tukik yang telah lepas dari cangkang telur, masih hidup namun masih berada dalam sarang (LIN). Jumlah tukik yang telah lepas dari cangkang telur, namun mati dan masih berada dalam sarang (DIN) (DKP, 2009).

\section{Analisis data}

Data yang diperoleh kemudian di analisis secara deskriptif dan kuantitatif dengan menggunakan Microsoft Excel. Pengolahan data sukses penetasan telur dilakukan secara kuantitatif dengan menggunakan rumus DKP (2009) sebagai berikut:

$$
\text { Sukses Penetasan }(100 \%)=\frac{(\mathrm{E}+\mathrm{LIN}+\mathrm{DIN}) \times 100}{\mathrm{CS}}
$$

dimana,

$\mathrm{E}=$ Tukik yang muncul ke permukaan LIN= Tukik yang berada dalam sarang DIN= Tukik yang mati dalam sarang $\mathrm{CS}=$ Jumlah telur dalam sarang

Kemudian data hasil analisis ditabulasi dalam bentuk tabel atau grafik menggunakan Microsoft Excel. Selanjutnya hasil olahan data di interpretasikan sesuai dengan tujuannya.

\section{HASIL DAN PEMBAHASAN Gambaran umum lokasi penangkaran Pantai Yenbekaki}

Yenbekaki terletak di sebelah timur pulau Waigeo, Kabupaten Raja Ampat. Berdasarkan jenis pasir, terdapat 2 jenis pantai yang ada di Yenbekaki yaitu pantai pasir putih dan pantai pasir hitam. Pantai pasir putih terletak di sekitar kampung Yenbekaki, sedangkan pantai pasir hitam terletak di depan timur kampung yang harus ditempuh melewati transportasi laut. Di pantai tersebut, terdapat aktivitas peneluran penyu yang sudah terjadi dalam waktu yang cukup lama. Oleh sebab itu masyarakat yang ada di kampung tersebut membentuk kelompok konservasi penyu. Selain dapat menjaga populasi penyu dari ancaman kepunahan, adanya kelompok ini juga diharapkan menjadi tambahan ekonomi bagi masyarakat yang ada di kampung tersebut.

Ancaman abrasi pantai dan perburuan telur untuk dikonsumsi oleh masyarakat masih sering terjadi. Sehingga kelompok konservasi penyu membuat tempat penangkaran untuk relokasi sarang. Tempat penangkaran tersebut berada di daerah pantai pasir hitam yang tidak terkena dampak air pasang tertinggi, yang terletak tidak jauh dari pos penjagaan, yang bertujuan lebih mempermudah dalam monitoring sarang. Tempat penangkaran ini dibangun di daerah pantai terbuka. Tempat penangkaran di buat berbentuk persegi panjang dengan lebar $5 \times 2$ meter. Disetiap sisi bawah dipasang papan yang bertujuan untuk menjaga sarang dari hewan seperti anjing. Dan pada sisi diatas papan di pasang jaring (Gambar 2). 


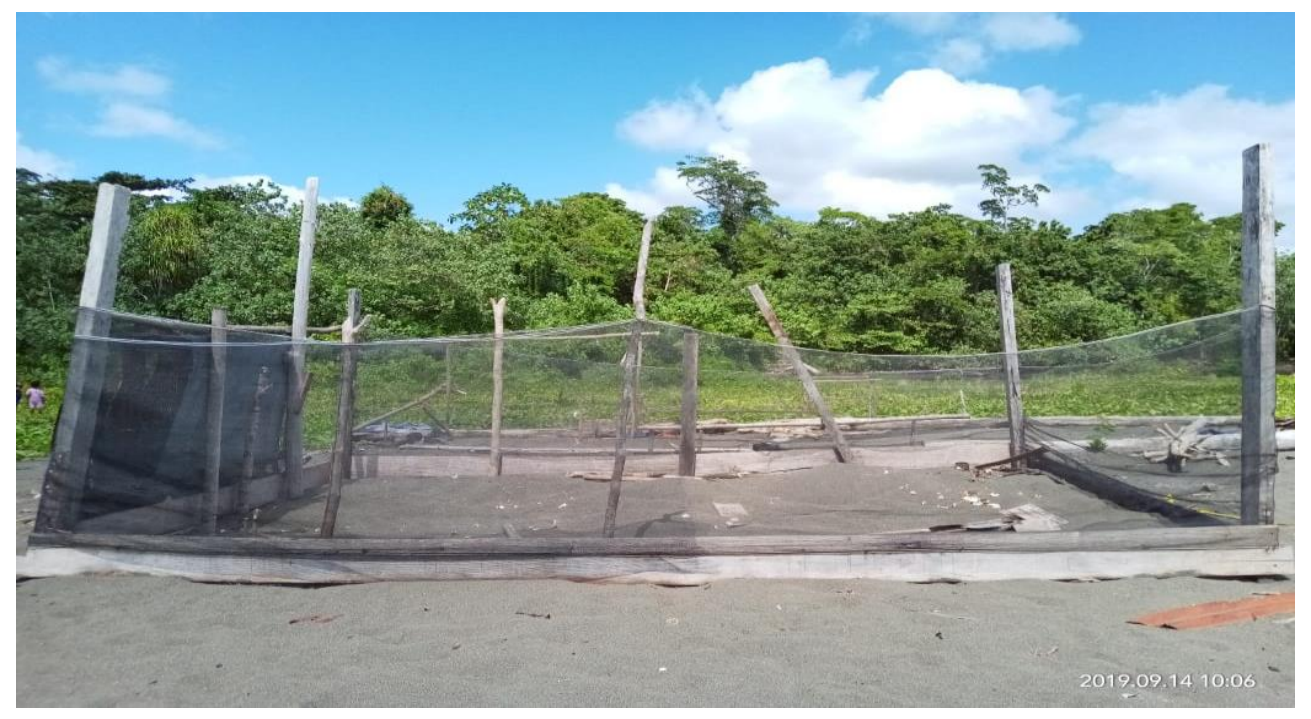

Gambar 2. Tempat Sarang Penangkaran

\section{Jumlah telur}

Jumlah keseluruhan sarang penyu yang diamati dalam penelitian ini adalah 19 sarang, yakni penyu lekang sebanyak 15 sarang dan penyu sisik sebanyak 4 sarang. Rata-rata jumlah telur penyu lekang adalah $92.1 \pm 2.37$ dengan kisaran 50-126 butir, sedangkan jumlah telur penyu sisik $112 \pm 0.86$ dengan kisaran 99-117 butir.

Hasil penelitian yang dilakukan di Yenbekaki menunjukan bahwa telur yang diletakkan oleh induk penyu bervariasi baik jumlah telur penyu lekang dan telur penyu sisik. Telur penyu lekang dengan kisaran 50-126 telur persarang, sedangkan telur penyu sisik dengan kisaran 99-117 persarang. Jumlah total telur penyu lekang adalah 1381 butir, sedangkan jumlah telur penyu sisik 448 butir. Kurangnya jumlah telur penyu sisik disebabkan karena masih belum memadainya transportasi monitoring di sekitar pantai pasir putih yang menjadi tempat peneluran penyu sisik.

\section{Sukses penetasan telur penyu Lekang dan Sisik}

Sukses penetasan adalah angka yang didapat dari jumlah tukik yang menetas dari seluruh telur yang diinkubasikan dalam sarang-sarang. Sukses penetasan penyu ditentukan dengan menghitung jumlah tukik yang keluar dari cangkangnya (DKP, 2009). Sukses penetasan penyu lekang dan penyu sisik pada lokasi penelitian (Gambar 3).

Berdasarkan hasil penelitian, diperoleh sukses penetasan pada sarang semi alami yaitu penyu lekang sebesar $71.6 \pm 28.3 \%$, sedangkan sukses penetasan telur penyu sisik sebesar $59.8 \pm$ $41.3 \%$. Suksesnya suatu penetasan dapat dilihat dari faktor pengelolaan, pemilihan tempat penetasan, perlakuan terhadap telur serta pengamanan tempat penetasan (Nuitja, 1983). Sukses penetasan pada sarang semi alami juga dipengaruhi oleh beberapa faktor seperti suhu inkubasi, predator, keterpaparan matahari dan penyakit (Ackerman, 1997). Rendahnya sukses penetasan pada telur penyu sisik disebabkan karena terdapat telur yang sudah mengeras yang kemudian dipindahkan ke sarang relokasi. Sehingga telur yang mulai berkembang terganggu akibat adanya goncangan yang menyebabkan perubahan posisi embrio dan terjadinya perubahan suhu. Hal ini senada dengan Hatasura 
(2004) yang mengatakan bahwa kegagalan telur menetas pada sarang relokasi disebabkan oleh guncangan saat pemindahan telur dari sarang alami ke sarang relokasi dan terjadinya perubahan suhu yang menjadikan telur tidak toleran pada kondisi tersebut.

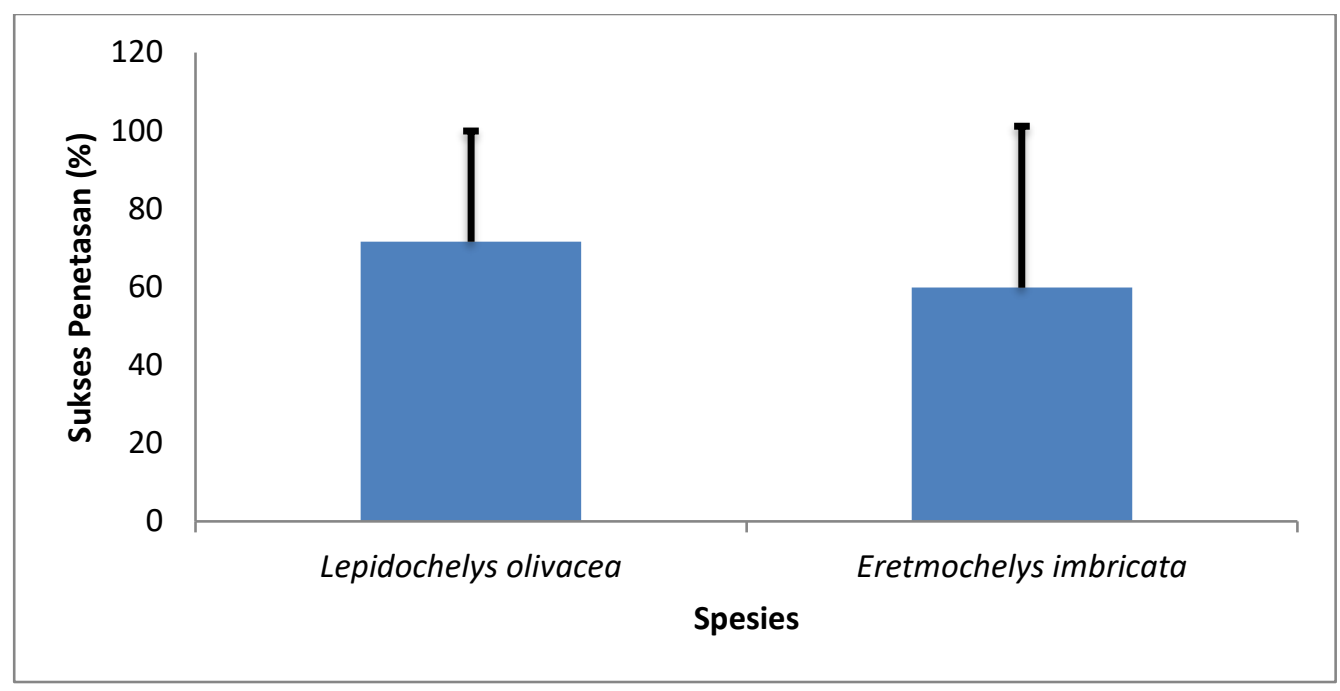

Gambar 3. Sukses Penetasan (Mean \pm SD) Telur Penyu Lekang dan Sisik

\section{Kegagalan Penetasan Telur}

Kegagalan penetasan telur penyu disebabkan oleh faktor eksternal yaitu lingkungan disekitar telur dan internal yaitu pada perkembangan telur itu sendiri. Berdasarkan hasil penelitian ini diketahu bahwa telur gagal menetas didominasi oleh tidak berkembangnya telur atau hanya dijumpai kuning telur dengan jumlah 506 butir dan kemudian disebabkan oleh intrusi akar 47 butir. Berdasarkan spesies, pada penyu lekang, dijumpai hanya kuning telur sebesar 370 butir dan karena pengaruh intrusi akar 39 butir. Sedangkan pada penyu sisik kuning telur 175 butir dan intrusi akar 8 butir. Tidak berkembangnya telur disebabkan karena saat pemindahan telur ke sarang relokasi terjadi goncangan atau telur yang sudah masuk dalam tahap stadia telur dipindahkan ke sarang relokasi sehingga terjadi perubahan posisi embrio (Hatasura, 2004). Faktor yang disebabkan oleh akar disebabkan karena pada saat penelitian, disekitar sarang relokasi ditumbuhi oleh tumbuhan pantai. Sehingga hal ini menjadi tantangan besar bagi sukses penetasan telur penyu.

\section{Suhu inkubasi sarang penyu lekang}

Suhu inkubasi sarang didapat dengan menggunakan logger suhu yang ditanam didalam sarang mulai dari telur diletakkan hingga telur menetas (Gambar 4). 


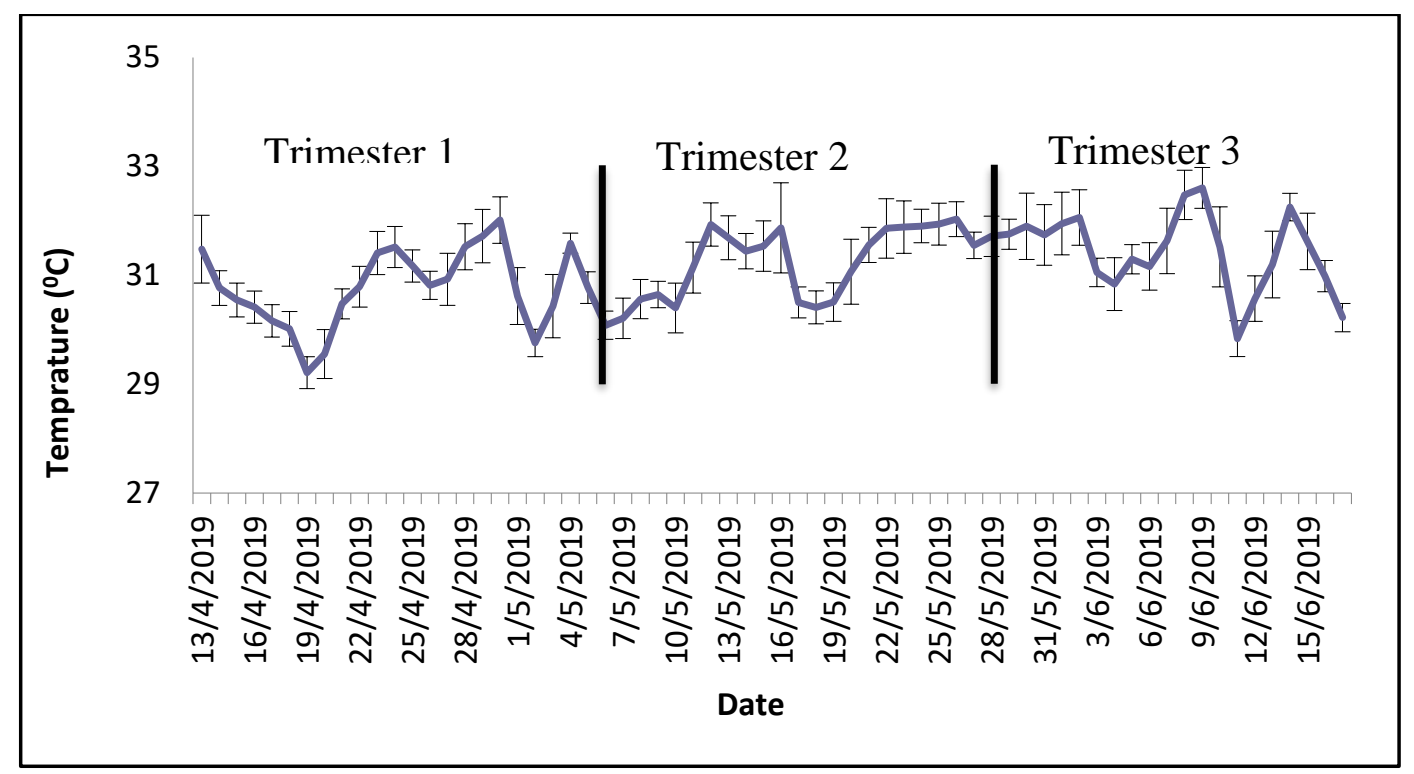

Gambar 4. Suhu Inkubasi Sarang Penyu Lekang

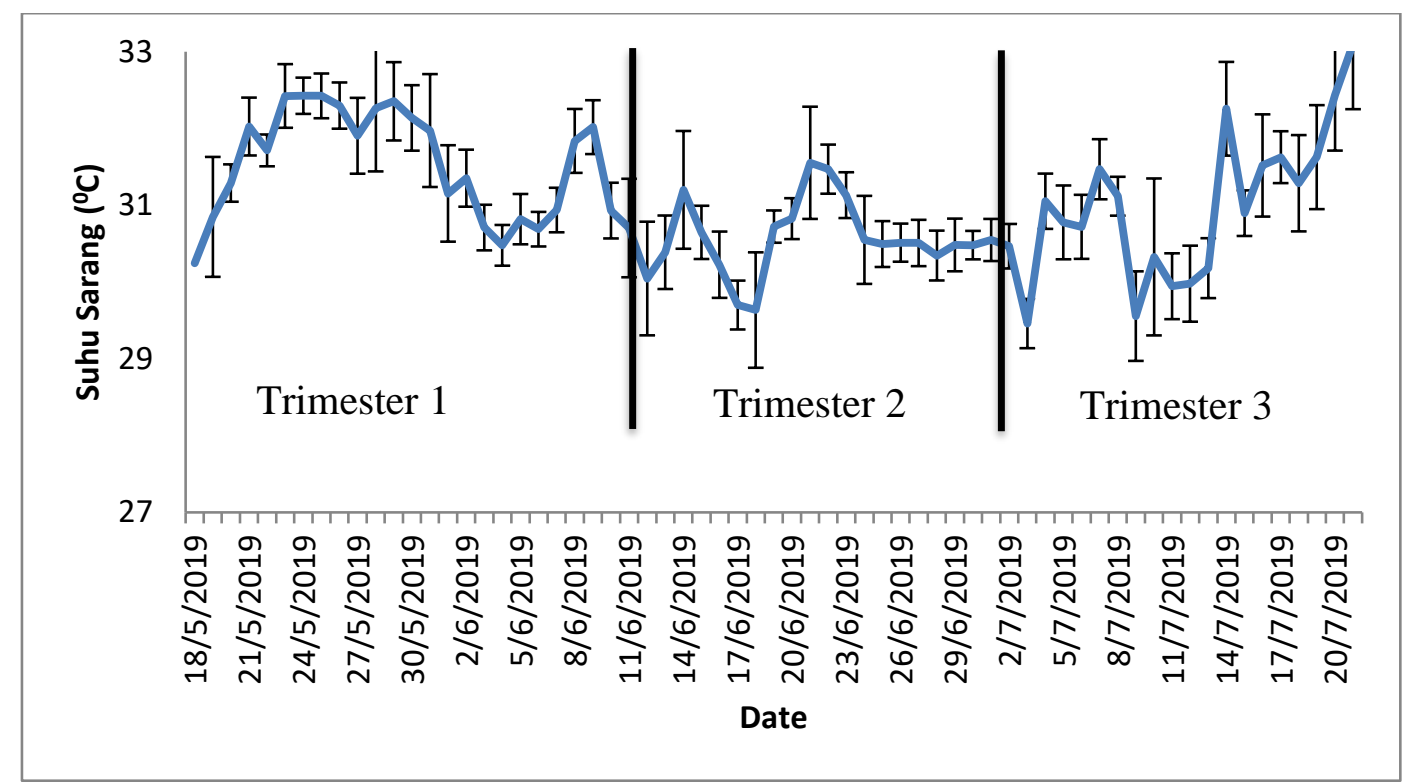

Gambar 5. Suhu Inkubasi Sarang Penyu Sisik

Dari gambar diatas dapat dilihat bahwa kisaran suhu sarang penyu lekang adalah $29-32 .{ }^{\circ} \mathrm{C}$ dengan rata-rata suhu inkubasi $31^{\circ} \mathrm{C}$ sedangkan rata-rata suhu inkubasi sarang penyu sisik $31^{\circ} \mathrm{C}$ dengan kisaran suhu $29-33^{\circ} \mathrm{C}$. Profil suhu sarang dibagi menjadi tiga tahap yaitu trimester 1, 2 dan 3. Pada tiap sarang terjadi peningkatan suhu tiap mesternya. Hal ini disebabkan oleh produksi panas metabolik yang meningkat selama tahap akhir inkubasi (Godley et al, 2002). Metabolisme ini mengubah senyawa sederhana menjadi lebih kompleks yang membentuk embrio sampai tukik. Besar rendahnya suhu inkubasi juga dipengaruhi oleh curah hujan, kelembapan dan kedalaman sarang (Suprapti et al, 2007). Pada saat penelitian, curah hujan yang ada diwilayah tersebut sangat rendah. Sehingga suhu inkubasi sarang penyu lekang dan penyu sisik tinggi. 
Suhu inkubasi berpengaruh terhadap keberhasilan penetasan telur. Menurut Wibbels (2000), jika temperature selama masa inkubasi jauh lebih rendah atau lebih tinggi dari temprature optimal $27-32^{\circ} \mathrm{C}$ maka hasil penetasan akan kurang dari $50 \%$. Hasil menunjukkan bahwa temprature berada dalam kisaran optimal yaitu $29-33^{\circ} \mathrm{C}$. Sesuai faktor lingkungan ini bahwa telur yang menetas seharusnya lebih dari 50\%. Hasil penelitian ditemukan bahwa penetasan telur kedua jenis penyu lebih dari 50\%.

Suhu inkubasi juga menjadi penentu pembentukan kelamin tukik. Tapilatu dan Ballamu (2015) mengatakan bahwa pada suhu inkubasi diatas $30^{\circ} \mathrm{C}$ maka tukik akan cenderung berkelamin betina, sedangkan apabila suhu inkubasi dibawah $29^{\circ} \mathrm{C}$ maka tukik akan cenderung berkelamin jantan. Dan bila suhu inkubasi $29^{\circ} \mathrm{C}$ maka rasio tukik jantan dan betina adalah 50\%:50\%. Dari pengukuran suhu tersebut maka rasio jenis kelamin tukik seluruhnya betina. Hal ini menjadi ancaman terbesar bagi keberlanjutan populasi penyu. Dimana apabila penyu betina lebih mendominasi di alam maka regenerasi penyu menjadi lambat.

\section{Suhu Pasir}

Suhu pasir didapat dengan menggunakan logger suhu yang ditanam di dalam pasir. Loger ditanam di dibawah naungan vegetasi yang tidak terkena dampak pasang surut. Loger ini ditanam dengan kedalaman $80 \mathrm{~cm}$ yang menggambarkan kedalaman sarang penyu belimbing (DKN, 2009). Suhu pasir ini kemudian disandingkan dengan kedua suhu sarang telur penyu.

Dari Gambar 6 dapat dilihat ratarata suhu pasir adalah $28^{\circ} \mathrm{C}$ dengan kisaran suhu $26-29^{\circ} \mathrm{C}$. Suhu pasir tertinggi terjadi pada pertengahan bulan mei dan suhu pasir terendah pada pertengahan bulan juli. Rendahnya suhu pasir dikarenakan berada dibawah naungan vegetasi dan kedalaman yang tinggi. Susilowati (2002) mengatakan bahwa terjadi fluktuasi suhu pada kedalaman $15 \mathrm{~cm}$ kebawah dan akan semakin menurun semakin kedalam.

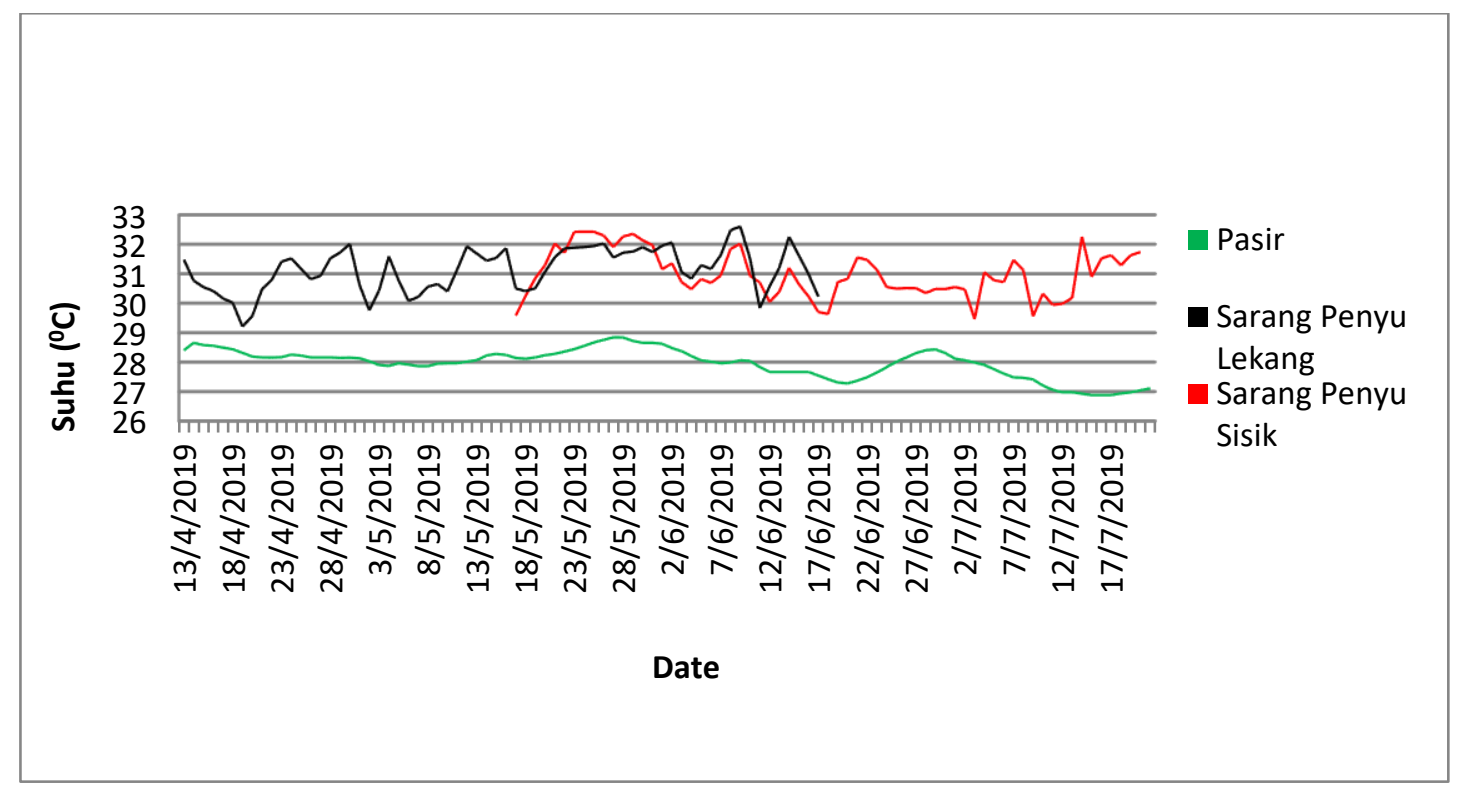

Gambar 6. Suhu Pasir, Sarang Penyu Lekang dan Sarang Penyu Sisik 
Hubungan suhu pasir, suhu sarang Penyu Lekang dan suhu sarang Penyu Sisik

Hubungan suhu pasir dengan suhu kedua sarang penyu (Gambar 6). Pada awal, suhu pasir sebesar $28^{\circ} \mathrm{C}$, suhu sarang penyu lekang $31^{\circ} \mathrm{C}$ dan suhu sarang penyu sisik $29^{\circ} \mathrm{C}$. Suhu pasir dengan suhu kedua sarang penyu mempunyai perbedaan $3-5^{\circ} \mathrm{C}$. Posisi pasir yang berada di bawah zona vegetasi menyebabkan terjadinya perbedaan suhu. Perbedaan kedalaman antara pasir dan sarang juga menjadi faktor yang mempengaruhi perbedaan suhu (Susilowati, 2002). Pola profil suhu antara pasir dan sarang menunjukkan relatif sama. Hal ini dapat dilihat ketika suhu pasir naik, suhu sarang juga naik dan begitu sebaliknya.

\section{KESIMPULAN}

Berdasarkan hasil penelitian ini maka dapat ditarik kesimpulan sebagai berikut:

1. Jumlah telur penyu lekang adalah 1381 butir, jumlah telur penyu sisik adalah 448 butirdan jumlah telur penyu belimbing adalah 47 butir.

2. Rata-rata sukses penetasan telur penyu lekang adalah $71.6 \pm 28.3 \%$ sedangkan sukses penetasan penyu sisik adalah $59.8 \pm 41.3 \%$.

3. Kondisi kegagalan penetasan telur penyu didominasi oleh kuning telur yang tidak memiliki embrio dan kemudian intrusi akar.

4. Rata-rata suhu inkubasi penyu lekang adalah $31^{\circ} \mathrm{C}$ dengan kisaran profil $29-32^{\circ} \mathrm{C}$, rata-rata suhu inkubasi sarang penyu sisik adalah $31^{\circ} \mathrm{C}$ dengan kisaran $29-33^{\circ} \mathrm{C}$ sedangkan rata-rata suhu pasir $28^{\circ} \mathrm{C}$ dengan kisaran profil $26-29^{\circ} \mathrm{C}$.

\section{DAFTAR PUSTAKA}

Bustard, R. 1972. Sea Turtles, Natural History and Conservation. Taplinger Publishing Company, New York. 220p.

Dermawan A., I.N.S, Nuitja., D, Soedharma., M.H, Halim, M.D, Kusrini., S.B, Lubis., R, Alhanif., M, Khazali., M, Murdiah., P.L, Wahjuhardini., Setiabudiningsih., A, Mashar.. 2009. Pedoman Teknik Pengelolaan Konservasi Penyu. Direktorat Konservasi dan Taman Nasional Laut. Dirjen KP3K, DKP RI Jakarta.

Dapertemen Kelautan dan Perikanan. 2009. Pedoman Teknis Pengelolaan Konservasi Penyu dan Habibatnya. Departemen Kelautan dan Perikanan. Jakarta

Godley, B.J., Broderik, A.C., Glen, F., Hays, G.C. 2002. Temprature Dependent Sex Determination of Ascension Island Green Turtle. Mar. Ecol Prog Ser 210: 115-124

Hasanah, K. 2013. Uji Korelasi Produk Moment Statistika Pendidikan.UNJ. Jakarta.

International Union for the Conservation of Nature and Natural Resources. https://www.iucnredlist.org/species/4615/11037468

Miller, J. D. 1997. Reproduction In Sea Turtles. In: Lutz, P.L dan Musick, J.A. The Biology of Sea Turtle. Boca Raton: CRC Press

Natih, N.M.N. 1989. Tingkah Laku Penyu Hijau (Chelonia mydas) di Pantai Pangumbahan. Jurusan Management Sumber Daya Perairan, Fakultas Perikanan. Bogor. (hlm 31)

Nuitja, I.N.S and Uchida. 1983. Study and The Sea Turtle II : The Nesting Site Characteristic of The Howks- 
bill and Green Turtle. Laboratorium Ilmu Kelautan UI-Institut Pertanian Bogor. Ancol. Jakarta

Nuitja, I.N.S. 1992. Biologi dan Ekologi Pelestarian Penyu Laut. IPB Presss, Bogor. $127 \mathrm{Hlm}$

Parinding, Z., Basuni, S., Purnomo, H., Kosmaryadi, N., dan Wardianto, Y. 2015. Karakteristik Fisik Pantai Peneluran Chelonia mydas, Linn.1758 di Kalimantan-Papua Barat. Jurnal Ilmu Pertanian Indonesia. Vol.20 No.1.

Sugiyono. 2007. Metode Penelitian Kunatitatif Kualitatif dan R\&D. Alfabeta. Bandung.

Susilowati, T. 2002. Studi Parameter Biofisik Pantai Peneluran Penyu Hijau (Chelonia mydas) di Pantai Pangumbahan Sukabumi, Jawa Barat. ISSN 0853-7291: Vol. 19(2):123-130

Tapilatu, R. F., and M. Tiwari. 2007. Leatherback turtle, Dermochelys coriacea, hatching success at Jamursba-Medi and Wermon beaches in Papua, Indonesia. Chelonian Conservation and Biology 6:154-158.

Tapilatu, RF dan Ballamu, F. 2015. Nest Temperatures from the Piai and Sayang Islands Green Turtle (Chelonia mydas) Rookeries, Raja Ampat Papua, Indonesia: Implications for Hatchling Sex Ratios. BIODIVERSITAS 16 (1): 102-107.
Tapilatu, R.F., Wona, H. and Batubara, P.P. 2017. Status of Sea Turtle Populations and its Conservation at Birds Head Seascape, Western Рариа, Indonesia. Biodiversitas 18(1):129-136

Tapilatu, R.F. 2017. The evaluation of nest relocation method as a conservation strategy for saving sea turtle populations in the North Coast of Manokwari - Papua Barat Province - Indonesia. Ecology Environment and Conservation 23(4):24-33

Wibbels, T., R. Marques, M. M. Garduso, D. Patrick and J. Pesa. 2000. Incubation temperatur in Kimp's Ridley Nest During the 1998, Nesting Season. Proceedings Nineteeth Annual Symposium on Sea Turtle Conservation and Biology, NMFS Publication. Miami. P: 130- 134

Yusuf. 2000. Mengenal Penyu. Yayasan Alam Lestari dan Keidanren Nature Conservation Fund (KNCF) Jepang. $81 \mathrm{hlm}$.

Upuya, J.S.2018. Sukses Penetasan Telur Penyu Di Hatchery Semi Alami Di Kampung Mubraidiba Distrik Manokwari Utara Kabupaten Manokwari. SKRIPSI FPIK. Universitas Papua 